PATRYCJA EWA HEROD
WNHIS UKSW, Warszawa

Acz myedzy nyekthorimy ludzmy kthorego kolibi stadla bily valka albo zwada przygodzylabi syan thedi on komu oczyecz brath abo ktho s prziyaczol przes nyekogo bilbi zabith, schvkacz crzywego i patrzacz ma, ale sprawyedliwego nyema gabacz paklibi smyalosczyąn zlosczywąn prawego $w$ domu albo procza domu nagabal tedi ten czo nagaba czczy i gymyenya ma bycz zbawyon, a ossobnye se schiyan varowacz syąn musi.

O mązoboysthwye, ust. 7 statutu z 27 kwietnia 1377 r., wydanego w Sochaczewie przez Ziemowita III, w przekładzie Macieja z Różana ${ }^{1}$

\title{
REGULACJE W ZAKRESIE PRAWA KARNEGO W STATUCIE SOCHACZEWSKIM Z 27 KWIETNIA 1377 ROKU
}

Po śmierci księcia Bolesława II Mazowieckiego² w 1313 r., następnym, a zarazem ostatnim, suwerennym władcą całego Mazowsza był dopiero Ziemowit III $^{3}$, który panował nad wszystkimi ziemiami mazowieckimi od 1370 r. do przełomu lat 1373/74, kiedy wyznaczył

\footnotetext{
1 Prawa książąt mazowieckich / przet. na jęz. pol. przez Macieja z Różana r. 1450, przedr. homograficzny z kodeksu kórnickiego wyk. A. Piliński, Kórnik 1877, s. 2 (według paginacji przyjętej przez autorkę artykułu, wobec niepoczynienia numeracji przez Macieja z Różana); por. J. Lelewel, Księgi ustaw polskich i mazowieckich, Wilno 1824, s. 134; zob. Iura Masoviae Terrestria: pomniki dawnego prawa mazowieckiego ziemskiego (dalej: IMT), wyd. J. Sawicki, t. 1 (1228-1471), Warszawa 1972, nr 22, art. 7: Actor homicidii queratur, s. 30.

2 Bolesław II (ok. 1253/58-1313), syn Ziemowita I, brat Konrada II. Współrządził z bratem do r. 1275, kiedy to w wyniku podziału Mazowsza został księciem płockim, w latach 1288-89 w Sandomierzu, od 1294 r. rządził całością Mazowsza. [O. Balzer, Genealogia Piastów, Kraków 1895, s. 421-423; J. Grabowski, Dynastia Piastów mazowieckich. Studia nad dziejami politycznymi Mazowsza, intytulacją i genealogia książat, Kraków 2012, s. 272275, K. Jasiński, Rodowód Piastów mazowieckich, Poznań-Wrocław 1998, s. 16-23; Zob. B. Horodyński, Bolesław II (zm. 1313), Polski Słownik Biograficzny (dalej: PSB), t. 1-7, Kraków 1935-58; t. 8-15, Wrocław-Warszawa-Kraków 1959-70; t. 16-25, Wrocław-Warszawa-Kraków-Gdańsk 1971-1980; t. 26-31, Wrocław-Warszawa-Kraków-Gdańsk-Łódź 1981-88; t. 32-34, Wrocław-Warszawa-Kraków 1989-93; t. 35-50, Warszawa-Kraków 1994-2015, t. 2, s. 267].

3 Ziemowit III (1316/25-1381), syn Trojdena I, brat Bolesława Jerzego II oraz Kazimierza I. Od 1341 r. współrządzący z bratem Kazimierzem I w Warszawie i Czersku, od 1345 r. w ziemi rawskiej, od ok. 1349 r. w wyniku podziału książę na Czersku, Liwie i Rawie, od 1351 r. w Gostyninie, od 1351 r. lennik Polski, od 1352 r. zastawny książę Płocka, od 1355 r. w Warszawie i Sochaczewie, od 1370 r. władca suwerenny, także w Płocku, od 1370 r. w Zakroczymiu i Wiźnie. [O. Balzer, Genealogia, op. cit., s. 457-458; J. Grabowski, Dynastia, op. cit., s. 288-297,
} 
dzielnice swoim synom, Ziemowitowi $\mathrm{IV}^{4}$ oraz Januszowi I Starszemu ${ }^{5}$. Ponowna niezależność ziemi mazowieckiej była konsekwencją śmierci króla Kazimierza III Wielkiego, który zmarł 5 listopada 1370 r., nie pozostawiając żadnego legalnego potomka w linii męskiej. Zgodnie z układami z 27 grudnia 1355 r. było to obligatoryjnym warunkiem wygaśnięcia zależności lennej Mazowsza od Królestwa Polski, albowiem homagium księcia Ziemowita III zostało ograniczone wyłącznie do osoby króla i jego potencjalnych męskich potomków ${ }^{6}$. W polityce wewnętrznej dux Masoviae mógł również poszczycić się doniosłymi dokonaniami. Wdrożenie około połowy XV w. nowego podziału administracyjnego stanowiło preludium poważnej reformy administracyjno-sądowej, która ukształtowała trzy hierarchie urzędnicze: dworską, ziemską i administracyjną, a także stała się fundamentem ziemskiego systemu sądowego. Po tak doniosłych reformach oraz scaleniu wszystkich ziem mazowieckich pod jednym berłem, było rzeczą oczywistą, że mazowieckie prawo zwyczajowe winno zostać zunifikowane, spisane i promulgowane.

Prawo zwyczajowe, stanowiące zbiór niepisanych norm prawnych powstałych w wyniku zachowań praktykowanych przez członków danej grupy za aprobatą większości i publicznie, stanowiło podstawowe źródło prawa na Mazowszu niemalże do końca XIV w. Zwyczajowy charakter prawa nie przesądzał o jego niezmienności, ponieważ praktyka sądowa dostosowywała zwyczaj (obyczaj) do zmieniających się okoliczności i potrzeb. Aż do przerwania samodzielnego bytu państwa mazowieckiego, w dyplomach zarówno publicznych, jak i prywatnych, a nawet w statutach, wielokrotnie powoływano się na zwyczaj jako źródło ich obowiązywania, co implikuje wniosek, iż prawo zwyczajowe niezmiennie cieszyło się ogromnym autorytetem wśród rodzimej ludności. Przejaw dążenia do ujednolicenia zwyczajów oraz przystosowania ich do nowych warunków społecznych był wyraźnie uwidoczniony w działalności statutowej książąt mazowieckich. Statuty (statuta, articuli terrestres) były pisanymi ustawami regulującymi wszystkie dziedziny prawa zarówno materialnego, jak i procesowego, przy czym mazowieckie statuty wybitnie hołdowały regulacjom z zakresu postępku sądowego (processus iudiciarius).

Najstarszy statut mazowiecki został wydany 27 kwietnia 1377 r. w Sochaczewie przez księcia Ziemowita III, przy udziale jego synów, Janusza I Starszego oraz Ziemowita IV, a także najprzedniejszych dostojników w państwie. Oryginał niniejszego aktu nie ostał się, zaś tekst znany jest z czterech rękopiśmiennych kopi, z których dwie obecnie są zaginione?

443-444; K. Jasiński, Rodowód Piastów mazowieckich, op. cit., s. 61-68; Zob. K. Jasiński, Siemowit III (ok. 1320 1381), PSB, t. 37, s. 73-75].

4 Ziemowit IV (ok. 1353/56-1425/26), syn Ziemowita III, brat Janusza I oraz Henryka Mazowieckiego. W wyniku podziału od 1381 r. książę na Rawie, Płocku, Sochaczewie, Gostyninie, Płońsku i Wiźnie, od 1386 r. dziedziczny lennik Polski, od 1388 r. w Bełzu. [O. Balzer, Genealogia, op. cit., s. 473-475; J. Grabowski, Dynastia, op. cit., s. 298-318, 450-451; K. Jasiński, Rodowód Piastów mazowieckich, op. cit., s. 87-91; Zob. A. Supruniuk, Siemowit IV (ok. 1352-1426), PSB, t. 37, s. 76-81].

5 Janusz I Starszy (ok. 1346-1429), syn Ziemowita III, brat Ziemowita IV oraz Henryka Mazowieckiego. W wyniku podziału od 1381 r. książę w Warszawie, Nurze, Łomży, Liwie, Ciechanowie, Wyszogrodzie i Zakroczymiu, od 1386 r. dziedziczny lennik Polski, od 1391 r. na Podlasiu. [O. Balzer, Genealogia, op. cit., s. 465-467; J. Grabowski, Dynastia, op. cit., s. 345-354, 444-450; K. Jasiński, Rodowód Piastów mazowieckich, op. cit., s. 78-83; Zob. B. Sobol, Janusz I Starszy (ok. 1329-1429), PSB, t. 10, s. 581-582].

$6 \quad$ Nowy kodeks dyplomatyczny Mazowsza (dalej: NKDM), red. J. Sułkowska-Kuraś, S. Kuraś, cz. 2: Dokumenty z lat 1248-1355, Wrocław 1989; cz. 3: Dokumenty z lat 1356-1381, red. J. Sułkowska-Kuraś, S. Kuraś, Wrocław 2000, cz. 2, nr 338-340.

7 Kod. Bibl. Petersb. Lat. Q II 274, f. 17-18v (zaginiony); Kod. Bibl. Kórnickiej tzw. Dziatyńskich V (D V) (zaginiony); AGAD, MK t. 1 f. 1-4; AGAD, Arch. Publ. Potockich, rkp. nr 4. [IMT, t. 1, s. 28]. 
Omawiany akt został ogłoszony także drukiem, wraz z innymi statutami, przez: Jana Wincentego Bandtkiego w Ius Polonicum ${ }^{8}$, Antoniego Helcla w Starodawnych prawach polskiego pomnikach ${ }^{9}$ oraz Jakuba Sawickiego w Iura Masoviae Terrestria: pomnikach dawnego prawa mazowieckiego ziemskiego ${ }^{10}$.

Jednocześnie warty szczególnej uwagi jest przekład statutu na język staropolski, dokonany przed 1450 r. ,,na przykazanie” księcia Bolesława IV Warszawskiego ${ }^{11}$ przez księdza Macieja z Różana ${ }^{12}$. Tekst zachował się w pergaminowym rękopisie, nazywanym Kodeksem Puławskim, w którym otwiera jako pierwszy zbiór statutów mazowieckich z lat 1377-1426 ${ }^{13}$. Przedmiotowy pomnik został w całości, z zachowaniem oryginalnej pisowni, wydany przez Joachima Lelewela $\mathrm{w}$ roku $1824^{14}$. Nadto jego przedruk homograficzny, wykonany przez Adama Pilińskiego, został ogłoszony drukiem staraniem Biblioteki Kórnickiej w 1877 r. W obliczu braku danych źródłowych nie da się ustalić, czy Maciej z Różana pracując nad przekładem statutów poczynił w nich jakieś zmiany w porównaniu z tłumaczonym pierwowzorem, który nie musiał być identyczny z oryginalnym tekstem ${ }^{15}$.

Statut sochaczewski z 27 kwietnia 1377 r. wykazuje w poszczególnych redakcjach różnice zarówno w treści artykułów, jak i pod względem ich liczby oraz układu, ale podkreślić należy, iż w żadnej edycji nie pominięto wstępu. W redakcji Bandtkiego oraz Sawickiego wzmiankowany akt dzieli się na 17 artykułów, zaś u Helcla na 18, przy czym edycja Sawickiego jest podstawowym wydaniem łacińskim wykorzystanym w prezentowanych rozważaniach ${ }^{16}$. Natomiast w przekładzie Macieja z Różana niniejszy akt zawiera aż 20 ustępów, spośród których dwa nie zostały uwzględnione w żadnym wydaniu łacińskim, tj. Gwalt kmyotownye (XVII) i Manzoboystwo kmyecza (XVIII), zaś ze względu na to, że zawierają regulacje z zakresu prawa karnego są bardzo istotne na gruncie omawianej problematyki.

Pierwszym przepisem karnym w statucie ogłoszonym przez Ziemowita III w 1377 r. jest ustęp czwarty, który został uwzględniony w każdej edycji w tym samym miejscu.

\footnotetext{
8 Ius Polonicum (dalej: IP), wyd. J. Bandtkie, Warszawa 1831, s. 417-420.

$9 \quad$ Starodawne prawa polskiego pomniki poprzedzone historyczno-krytycznym tak zwanego prawodawstwa wiślickiego Kazimierza Wielkiego w texcie ze starych rękopism krytycznie dobranym (dalej: H), wyd. A. Helcel, t. 1, Warszawa 1856, s. 269-274.

10 IMT, t. 1, nr 22, s. 28-33.

11 Bolesław IV Warszawski (1418/20-1454), wnuk Janusza I, od r. 1429 książę ciechanowski, czerski, liwski, łomżyński, nurski, różański, warszawski, wyszogrodzki i zakroczymski (od 1436 r. rządy samodzielne, wcześniej regencja matki Anny Fiodorównej), w 1. 1440-44 książę podlaski. [O. Balzer, Genealogia, op. cit., s. 521-522; J. Grabowski, Dynastia, op. cit., s. 356, 477-478; K. Jasiński, Rodowód Piastów mazowieckich, op. cit., s. 157-160; Zob. K. Maleczyński, Bolesław IV (1421-1454), PSB, t. 2, s. 280-281].

12 Maciej z Różana, zwany Maciejem Różańskim (ok. 1420-1467), kanclerz mazowiecki, pisarz skarbny, kanonik płocki i warszawski, proboszcz czerski i makowski. [Zob. I. Sułkowska Kurasiowa, A. Wolff, Maciej z Różana (ok. 1420-1467), kanclerz księcia mazowieckiego Bolesława IV, PSB, t. 19, s. 35-36]; S. Kutrzeba, Historia źródet dawnego prawa polskiego, t. 2, Lwów-Warszawa-Kraków 1926, s. 11.

13 W przedmiotowym zbiorze znajduje się także przekład statutów polskich, dokonany przez Świętosława z Wojcieszyna. [O. Balzer, Słowo o przekładach polskich statutów średniowiecznych zwłaszcza o kodeksie dzikowskim przekład taki zawierającym, Lwów 1888, s. 6-7].

14 J. Lelewel, Księgi, op. cit., s. 133-152.

15 S. Russocki, Z badań nad statutami książat mazowieckich z XIV i XV wieku, „Czasopismo Prawno-Historyczne” nr 8/1956, z. 2, s. 246.

16 Odmienności w powyższych edycjach będą wykazywane na bieżąco w przypisach.
} 
U Sawickiego zatytułowany Praescripcio maleficiorum ${ }^{17}$, zaś w tłumaczeniu Macieja z Różana $O$ vivolanych zloczinczach ${ }^{18}$. Omawiany przepis nakładał na książąt Ziemowita III, Janusza I Starszego oraz Ziemowita IV obowiązek sporządzenia spisu wszystkich przestępców, bez względu na przynależność stanową, którzy dopuścili się w ich domenach tzw. łotrostw, tj. rozboju bądź złodziejstwa ${ }^{19}$, oraz przekazania sobie nawzajem niniejszych ustaleń na piśmie. Jednocześnie przedmiotowy ustęp wskazywał, że osoby ujęte w spisach mają zostać wywołane i dopóki nie udowodnią swojej niewinności i nie oczyszczą się, będzie grozić im kara adekwatna do przestępstwa, jakie popełnili.

Zawodowo uprawiane rabunki i kradzieże były przestępstwami zaliczanymi do najpoważniejszych oraz ściganymi z urzędu. Rozbojem (latrociniam) określano gwałty popełniane w celu grabieży i w razie wezwania zarówno wszyscy obywatele, jak i urzędnicy mieli obowiązek nie tylko ścigać i łapać rozbójników, ale także dostawić ich do właściwej miejscowo władzy ${ }^{20}$. Źródła mazowieckie, które dotrwały do czasów obecnych, nie określają kary, jakiej podlegał przestępca dokonujący rozboju, ale skoro za złodziejstwo groziła kara śmierci, a oba przestępstwa zaliczano do jednej kategorii, to wysoce prawdopodobne jest, że prawo mazowieckie przewidywało za rozbój taką samą sankcję. Natomiast kara proskrypcji, zwana inaczej wywołaniem, była ogłaszana publicznie po zapadłym zaocznie wyroku. Wywołanie powodowało tzw. śmierć cywilną (śmierć fikcyjna) proskrypowanego, który przestawał istnieć dla prawa jako osoba, a tym samym odbierano mu zdolność prawną i zdolność do czynności prawnych, a także konfiskowano cały jego majątek oraz zakazywano przebywania w granicach państwa ${ }^{21}$. Żona wywołańca stawała się w świetle prawa wdową i mogła wstąpić w nowy związek małżeński, zaś dzieci były uważane za sieroty ${ }^{22}$.

Abstrahując od powyższego, należy wskazać, że sporządzenie trzech spisów przez każdego księcia osobno było umotywowane ówczesnym podziałem ziem mazowieckich na trzy władztwa, dokonanym przez Ziemowita III pomiędzy 12 maja 1373 r. a 5 stycznia 1374 r. Wówczas Janusz I Starszy otrzymał ziemie: ciechanowską, wiską, warszawską i zakroczymską, Ziemowit IV czerską wraz z Liwem i rawską, zaś ich ojciec zatrzymał

\footnotetext{
17 „Item domini duces Semovitus senior, Iohannes et Semovitus iuniores, omnes suos malefactores seu fures vel latrones, cuiuscunque condicionis fuerint aut status conscribere [debent mandere] et eosdem unus ad alterum in scriptis enarrare. Et si quis ex eisdem prescriptis suam innocenciam et infamiam non curaverit expurgare, extunc iuxta factum suum, prout demeruit, licite sustinere debet”. [IMT, t. 1, s. 29-30]; U Bandkiego nie przyjęto żadnej numeracji, poprzestając na samych nagłówkach, zaś czwarty ustęp opatrzony jest tytułem Consriptio malefactorum [IP, s. 418]; Helcel wprowadził rzymską numerację w tekście łacińskim bez uwzględnienia tytułów, zaś obok każdego ustępu umieścił jego tłumaczenie na jęz. polski, poprzestając na podaniu nagłówków także w jęz. polskim, i art. IV w jego redakcji jest tożsamy z ustępem 4: Praescripcio maleficiorum u Sawickiego [H, s. 270].

18 „Item. Xąnąntha Semouith stari Jan i Semouith mlothschi wschithky swe zloczincze albo zlodzyeye lotri ktorego kolibi stadla albo powysschenya bili mayan popissacz a yeden od drvego napysmyenyv wszkazacz paklibi ktho tich violannich swey nyewinnosczy $i$ ganybi nyedbal oczisczicz tedi podlug vczinkv swego yako zasluzil dostoynie czyrzpyecz bandzye". [Prawa, op. cit., s. 2; por. J. Lelewel, Księgi, op. cit., s. 134].

19 W prawie mazowieckim należy rozróżnić pojedynczą kradzież od złodziejstwa, rozumianego jako uporczywe dokonywanie kradzieży o charakterze zawodowym.

20 Zob. przywilej ziemski z 18 IX 1447 r. dla szlachty powiatów nowogrodzkiego, łomżyńskiego, liwskiego, nurskiego, makowskiego, różańskiego, ostrowskiego i ostrołęckiego [IMT, t. 1, nr 94; por. Kodeks dyplomatyczny Księstwa Mazowieckiego, obejmujacy bulle papieżów, przywileje królów polskich i ksiażat mazowieckich, tudzież nadania tak korporacyj jako i osób prywatnych, red. J. Lubomirski, Warszawa 1863, nr 194].

21 J. Bardach, B. Leśnodorski, M. Pietrzak, Historia ustroju i prawa polskiego, Warszawa 2003, s. 160.

22 J. Rafacz, Dawne polskie prawo prywatne, Warszawa 1925, s. 22, 131.
} 
dożywotnio ziemie Mazowsza północno-zachodniego z Gostyninem, Płockiem, Płońskiem, Sochaczewem i Wyszogrodem ${ }^{23}$.

Ewidentnym dowodem na to, że na Mazowszu w drugiej połowie XIV w. złodziejstwo popełniano nagminnie i stanowiło to duży problem społeczny, jest poświęcenie temu zagadnieniu aż czterech artykułów w statucie z 1377 r. Ustęp ósmy, zatytułowany De inculpato pro forticinio ${ }^{24}$ w Iura Masoviae Terrestria, a w przekładzie Macieja z Różana podany jako artykuł dziewiąty i opatrzony nagłówkiem Gdi kogo obvynyąn o zlodzyestwo ${ }^{25}$, regulował sposób oczyszczenia się z zarzutu złodziejstwa (furtum, furticinium), który wyglądał tak samo zarówno w przypadku uprzedniego wniesienia oskarżenia, jak i samego podejrzenia o jego popełnienie, co traktowano jako ciężką zniewagę. Aby oczyścić się z zarzutu złodziejstwa, obwiniony miał obowiązek przyprowadzić do sądu sześciu krewnych z trzech linii rodu, tj. po dwóch z ojczystej, macierzystej oraz matki ojca, zarazem osiadłych i cieszących się dobrą sławą, którzy jako świadkowie mieli złożyć przysięgę oczyszczającą go z ciążących na nim zarzutów, przy czym sam nie mógł składać przysięgi we własnym imieniu.

Następną regulację w zakresie omawianego czynu zabronionego stanowił artykuł 11, Inculpatus pro furticinio per principem ${ }^{26}$, który w tłumaczeniu Różańskiego nosi tytuł $G d y$ xanząn obvyni kogo o zlodzyestwo ${ }^{27}$ i został umieszczony jako 12 . Na mocy powołanego przepisu złodziej, który został postawiony w stan oskarżenia przez księcia i nie dokonał oczyszczenia w ciągu 18 tygodni, podlegał karze śmierci oraz konfiskacie majątku zarówno ruchomego, jak i nieruchomego na rzecz władcy. Na marginesie należy zaznaczyć, że wskazane sankcje mogły dotyczyć tylko i wyłącznie przestępców, którzy oddawali się kradzieży zawodowo, czyniąc z niej źródło utrzymania ${ }^{28}$.

Kara śmierci (in collo punie, collo privare, collo persolvere, vita privari, caput amputare) mogła być zwykła, i wówczas wykonywano ją przez ścięcie albo powieszenie (suspensio), oraz kwalifikowana, kiedy łączyła się ze szczególnymi udręczeniami (np. zagłodzenie, ćwiartowanie, spalenie na stosie, otrucie czy pochowanie żywcem), przy czym prezentowany

\footnotetext{
23 NKDM, cz. 3, nr 136.
}

24 ,Item cum aliquis fuerit inculpatus pro forticinio vel diffamatus, talis sex testes producere debet, et illi testes pro ipso iurare debebunt, ipse autem solus non iurabit. Tamen eosdem testes de triplici geneloya producere debet pro sua infamia; quo utique testes terre seniores acceptabunt”. [IMT, t. 1, nr 22, s. 31]; U Bandkiego niniejszy artykuł został pominięty, zaś u Helcla znajduje się jako IX [H, s. 272].

25 „Item. Gdi ktho o zlodzyeystwo bandze obvynyon albo osromoczon taky schesczyąn swyatkow w sandze swoyąn nywynnoscz ocziscz a ony swyatkowye za nim mayan przissyancz a on sam nyema przissyangacz ale wschdi thi iste swyatky a troyga rodu o swoyąn sromothąn slawycz ma ktore wschdi starschi zemye prziymąn". [Prawa, op. cit., s. 3; por. J. Lelewel, Księgi, op. cit., s. 134].

26 ,Item quando princeps aliquem hominem pro furticinio inculpaverit, ipsum asserens furem, extunc eidem terminus ad sex septimanas, iterum ad secundas [sex] septimanas et superflue ad tercias sex septimanas assignetur et si iterum in eisdem decem et octo septimanis iustum se non fecerit, tunc princeps in sua bona hereditaria et mobilia se intromittere debebit, ipse autem cum collo suo debet se vitare". [IMT, t. 1, nr 22, s. 31]; U Bandkiego przedmiotowy artykuł został opatrzony nagłówkiem Modus justificandi, quibus crimen furti a principe obiicitur i znajduje się na dziesiątej pozycji [IP, s. 419], zaś u Helcla został podany jako XII [H, s. 272].

27 „Item. Gdi nyektere xanząn nyektorego czlowyeka o kradzecz o zlodzyeystwo obvyuilibi gdi zlodzyeyem myenyecz thedi yemu rok naprzod za schescz nyedzel a i daley na wthoran schescz nyedzyel a nadwischsche za trzeczyąn schescz nyedzyel ma bicz dan pakli w tey osmynaczcze nyedzel sprawyedlywi syąn wzruczicz a on s schiya ma syąu vyarowacz". [Prawa, op. cit., s. 3; por. J. Lelewel, Księgi, op. cit., s. 135].

28 Prawo mazowieckie rozróżniało także jednostkowe przypadki kradzieży. Przykładowo, za kradzież trawy z łąki groziła kara pieniężna określana mianem sześć grzywien (7,5 grosza), uiszczana zarówno na rzecz powoda, jak i ustanowionego przez księcia urzędnika. [Statut z 26 XI 1397 r., art. 2: De furto ponderis graminum, IMT, t. 1, nr 48, s. 71]. 
akt nie ustanawiał jej w żadnym przepisie. Ścięcie było uważane za najłagodniejszy oraz niehańbiący sposób wykonania wyroku, więc było zarezerwowane dla stanu uprzywilejowanego, zaś powieszenie postrzegano jako hańbiące i stosowano je najczęściej przy skazaniu za kradzież ${ }^{29}$. Natomiast kara konfiskaty majątku (bona perdere, bona confiscare) była uważana za bardzo dotkliwą, ponieważ z racji tego, że obejmowała także dobra rodowe, dotknięta nią była cała rodzina sprawcy, co w praktyce oznaczało przekreślenie pozycji społecznej nie tylko przestępcy, ale także jego bliskich ${ }^{30}$. Konfiskata majątku była najczęściej orzekana jako kara dodatkowa obok kary śmierci albo proskrypcji, czy infamii.

Jednocześnie ustęp 12, De eodem ${ }^{31}$ (w tłumaczeniu Macieja z Różana na pozycji 13, opatrzony nagłówkiem Zlodzey gdi vesmye ot plathąn wschitko zaplaczy ${ }^{32}$ ), wyłączał w odniesieniu do złodzieja, na którym została już wykonana kara śmierci przez powieszenie, karę konfiskaty majątku, który miał zostać zachowany w majestacie prawa przez jego żonę i dzieci. Jednakże niniejszy przepis musiał odnosić się do osób, które zapłaciły głową za popełnienie wzmiankowanego przestępstwa jeszcze przed ogłoszeniem aktu z 27 kwietnia 1377 r., albowiem w stosunku do złodziei dotychczas nieukaranych zastosowanie miał artykuł go poprzedzający.

Regulacje dotyczące złodziejstwa zamykał ustęp 13, Articulus ${ }^{33}$, który został umieszczony przez Macieja z Różana jako 14 i zatytułowany Gdi zlodzyeya w czudzey zemy obyeschąn xanza wesmye yego gymyenye ${ }^{34}$. Omawiany przepis wprowadzał kolejną odmienność w odniesieniu do kary konfiskaty majątku i normował sytuację prawno-karną sprawcy, który po dokonaniu przestępstwa w jednej ziemi, uciekł do innej, gdzie ostatecznie został powieszony. Wówczas konfiskacie na rzecz księcia podlegała tylko i wyłącznie ta część jego majątku rodowego, która przypadała mu z mocy prawa, zaś części przynależne jego braciom były spod niej wyłączone.

Ewenementem w skali całego prawodawstwa polskiego był artykuł siódmy statutu, który u Jakuba Sawickiego opatrzony jest nagłówkiem Actor homicidii queratur ${ }^{35}$, a w przekładzie

29 Pierwszym odnotowanym przypadkiem wykonania na Mazowszu wyroku śmierci przez powieszenie był casus Jana Czapli, scholastyka płockiego i włocławskiego, który został powieszony w 1239 r. na mocy wyroku księcia Konrada I Mazowieckiego. Z uwagi na to, że po wykonaniu kary ciało skazańca nie zostało pogrzebane i przewieszono je vis a vis katedry płockiej, należy uznać, że był to typ kwalifikowany powieszenia.

30 J. Bardach, B. Leśnodorski, M. Pietrzak, Historia, op. cit., s. 160.

31 „Item quando princeps aliquem furem suspendere mandaret, et aliquam super eo vindictam sumeret pro suis excessibus, tunc ad suam hereditatem vel ad sua bona ipse princeps minime intromittere se debebit, quia ipse omne debitum in collo suo persolvit, sed utique uxorem vel pueros ipsius in eisdem bonis residere debet permittere pacifice”. [IMT, t. 1, nr 22, s. 32]; U Bandkiego niniejszy przepis umieszczony jest jako 11 i został zatytułowany Fur totum delictum collo exsolvit [IP, s. 419], zaś u Helcla stanowi pozycję 13 [H, s. 272-273].

32 „Item. Gdi xanzan nyekterego zlodzyeya albo nyekteran zlodzyekąn obyesycz kazalbi a na tem pomstan vesma za gych grzech tegdi w gich dzyedzini albo gymyenya to iste xanzan w wyanzowacz albo wrzuczacz syąn nyema bo wschitek grzech schiyan swan zaplaczyli a wschdi zona i dzyeczy gich w gymyenyu mayan bicz przepusczeny pokoynye”. [Prawa, op. cit., s. 3; por. J. Lelewel, Księgi, op. cit., s. 135].

33 „Preterea, quando aliquis homo furticinium aliquod perpetraret, et postmodum fugeret in terram alienam, et ibidem in terra aliena suspenderetur, extunc dux in [et] ad omnia bona sua libere se intromittat, et ipsa bona perpetua obtineat". [IMT, t. 1, $\mathrm{nr} 22$, s. 32]; U Bandkiego wzmiankowany przepis umieszczono jako 12 i zatytułowano Fur in exilio suspensus [IP, s. 419], zaś u Helcla stanowi ustęp 14 [H, s. 273].

34 ,Item. Gdi nyekteri czlowyek zlodzyeystwo nyektore popelnylbi a potem bi s zyemye uczyekl w zyemyąn gyuschąn a tambi $w$ zjemy czvdzey obyeschon bil tegdi $w$ yego cząnscz dzyedzini pan xąnąn $w$ wyanzacz ma ale $w$ czanscz braczyey yego nyema syąn $w$ matacz ale dobrowolnye bes wschego vgabanya braczya se yego czansczy swe possyandą". [Prawa, op. cit., s. 4; por. J. Lelewel, Księgi, op. cit., s. 135].

35 „Item si inter aliquos homines, cuiuscunque condicionis extiterint, gwarra seu dissensio evenerit, extunc, ille, cui pater, frater vel quispiam ex amicis est interfectus, reum temptare et inspicere debebit, iustum vero non debebit impedire. Et si ausu temerario iustum in domo vel extra domum irritaverit, tunc honore et bonis suis privetur et 
Macieja z Różana nosi tytuł $O$ manzoboysthwye ${ }^{36}$ i stanowi motto do niniejszego tekstu. Wzmiankowany przepis był pierwszą regulacją na gruncie prawa mazowieckiego w zakresie

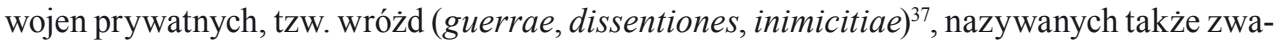
dami $^{38}$. Szczególnego podkreślenia wymaga fakt, iż w Koronie nie było żadnych przepisów, które regulowałaby warunki zemsty albo ją ograniczały. Konsekwencją mężobójstwa (zabójstwa) szlachcica (rycerza) przez osobę wywodzącą się także ze stanu uprzywilejowanego było powstanie stanu wróżdy pomiędzy rodziną zmarłego a rodziną zabójcy i uprawniało do usankcjonowanej przez prawo krwawej zemsty, którą objęci byli wszyscy członkowie rodu zabójcy, nawet dzieci, a także ich poddani ${ }^{39}$.

Natomiast omawiany ustęp kategorycznie zakazywał dokonania zemsty na innych członkach rodu, ograniczając odwet do samego zabójcy, pod groźbą utraty życia, infamii oraz konfiskaty całego majątku, co obrazowało skalę problemu w aspekcie bezpieczeństwa i porządku publicznego, skoro prawo przewidywało tak surową penalizację. Kara infamii (infamia, honorem perdere), tak samo jak proskrypcja, pociągała za sobą utratę czci szlacheckiej, ale odmiennie niż wywołanie nie łączyła się z wygnaniem z kraju, ponieważ zakładano, że infamis ma pędzić żywot w państwie, gdzie jego położenie zarówno prawne, jak i społeczne ma być upośledzone ${ }^{40}$. Przykładowo, objęty infamią był pozbawiony zdolności prawnej, w konsekwencji czego nie mógł między innymi stawać w sądzie, dzierżyć urzędów ani być stroną kontraktów prywatnych.

Do regulacji łączących się ściśle z przestępstwem mężobójstwa (homicidium) ${ }^{41}$ należy również zaliczyć ustępy określające wysokość główszczyzny, która była pieniężną karą prywatną i stanowiła sumę składaną za głowę zabitego na rzecz jego rodziny. Artykuł 15, Homicidium militis super militem ${ }^{42}$ (w przekładzie Różańskiego zatytułowany Gdi wlodika zabye wlodikąn i podany jako ustęp $16^{43}$ ), ustanowił wysokość główszczyzny za niższe ry-

precipue ipsum cum collo evitare opportebit”. [IMT, t. 1, nr 22, s. 30]; U Bandkiego powyższy ustęp znajduje się na końcu i jest zatytułowany Homicida quaeratur et justus dimittatur [IP, s. 420], zaś u Helcla został podany w tej samej kolejności [H, s. 271].

36 „Item. Acz myedzy nyekthorimy ludzmy kthorego kolibi stadla bily valka albo zwada przygodzylabi syan thedi on komu oczyecz brath abo ktho s prziyaczol przes nyekogo bilbi zabith schvkacz crzywego i patrzacz ma ale sprawyedliwego nyema gabacz paklibi smyalosczyąn zlosczywąn prawego $w$ domu albo procza domu nagabal tedi ten czo nagaba czczy i gymyenya ma bycz zbawyon a ossobnye se schiyan parowacz syąn musi”. [Prawa, op. cit., s. 2; por. J. Lelewel, Ksieggi, op. cit., s. 134].

37 „Item si inter aliquos homines, cuiuscunque condicionis extiterint, gwarra seu dissension evenerit... ”. [Statut z 27 IV 1377 r., art. 7: Actor homicidii queratur, IMT, t. 1, nr 22, s. 30].

38 „Acz myedzy nyekthorimy ludzmy kthorego kolibi stadla bily valka albo zwada... ”. [O manzoboysthwye, Prawa książąt mazowieckich..., s. 2].

39 J. Bardach, B. Leśnodorski, M. Pietrzak, Historia, op. cit., s. 157; Na ten temat zob. szerzej np. R Hube, Wróżda, wróżba i pokora, w: Romualda Hubego pisma, t. 1, Warszawa 1905, s. 312-335.

40 J. Rafacz, Dawne polskie prawo karne. Czesść ogólna, Warszawa-Kraków-Lublin 1932, s. 163; Na ten temat zob. szerzej np. B. Łoziński, Infamia studyum prawno-społeczne, Lwów 1987.

${ }_{41}$ Prawo mazowieckie, tak samo jak prawo koronne, nie wprowadziło rozróżnienia pomiędzy pojęciami zabójstwa a morderstwa. Z tego względu wszystkie czyny określane w innych ustawodawstwach jako morderstwo albo zabójstwo, na Mazowszu oznaczane były jednym terminem, tj. mężobójstwem.

42 „Item quando miles militem interfecerit, pro milite interfecto quadraginta marcas grossorum monete communis numerique in terra Mazovie currentis persolvere tenebitur interficiens". [IMT, t. 1, nr 22, s. 32]; U Bandkiego niniejszy ustęp oznaczono nagłówkiem Homicidium militis per militem i umieszczono na pozycji 14 [IP, s. 419], zaś w edycji Helcla został pominięty.

43 „Item. Gdi wlodika zabiye wlodikan za wladikąn zabytego cztirdzyesczy grziwen zaplaczycz bandzye vynen”. [Prawa, op. cit., s. 4; por. J. Lelewel, Księgi, op. cit., s. 135]. 
cerstwo, czyli włodyków, na 40 grzywien, tj. 20 kop groszy ${ }^{44}$. Jednocześnie należy wskazać, że zróżnicowanie warstwy szlacheckiej pod względem prawnym, a konkretnie w aspekcie kary główszczyzny, zostało po raz pierwszy sprecyzowane w statucie z 20 marca 1390 r., ogłoszonym przez księcia Janusza I Starszego, gdzie jej wysokość za głowę szlachcica ustalono na 48 kop groszy, zaś za głowę włodyki, tak jak dotychczas, na 20 kop groszy ${ }^{45}$.

W tłumaczeniu Macieja z Różana, odmiennie niż w wydaniach łacińskich, znajduje się także przepis kształtujący wysokość główszczyzny za zabójstwo kmiecia ${ }^{46}$, opatrzony nagłówkiem Manzoboystwo kmyecza i podany jako artykuł $18^{47}$. Na mocy powołanego ustępu zabójca musiał zapłacić rodzinie zabitego, tj. żonie i dzieciom, cztery kopy groszy oraz tyle samo księciu albo panu kmiecia (dziedzicowi).

Akt z 1377 r. regulował także wysokość nawiązki za pobicie bądź zranienie kmiecia przez szlachcica (rycerza), a także ustanawiał zasady dochodzenia sprawiedliwości na drodze postępku sądowego oraz wysokość tzw. bitego. Na zasadzie artykułu 14, Quantitas pene pro verbere kmethonum ${ }^{48}$, który u Różańskiego umieszczono jako 15 i zatytułowano Vyna gdi zyemyanym zbyye kmyeczya ${ }^{49}$, pobity albo zraniony kmieć miał obowiązek wnieść do sądu skargę, nazywaną żałobą, zaś jego pan musiał mu asystować przed wymiarem sprawiedliwości. W przypadku wygranej, pokrzywdzony miał otrzymać nawiązkę w wysokości sześciu skojców. Nawiązka była pieniężną karą prywatną, a jej wysokość zawsze stanowiła część ułamkową główszczyzny. Jednocześnie skazany musiał uiścić na rzecz pana poszkodowanego kmiecia osobną karę w wysokości trzech grzywien, tzw. bite (poena percussionalis lub percussionis), oraz karę publiczną na rzecz księcia, która w powołanym ustępie nie została konkretnie określona. Jednakże zaznaczyć należy, iż wymiar kar książęcych najczęściej równał się zadośćuczynieniu przewidzianemu przez prawo dla poszkodowanego, przy czym na gruncie niniejszego unormowania nie jest jednoznaczne, czy sprawca miał wpłacić do skarbu książęcego równowartość „,bitego” czy nawiązki.

\footnotetext{
44 W omawianym okresie grzywna na Mazowszu, inaczej niż w Koronie, liczyła 30 groszy, a więc płat wynosił 20 kop groszy, co stanowiło 25 grzywien polskich. [S. Kutrzeba, Mężobójstwo w prawie polskim XIV i XV w., Kraków 1907, s. 56]; Pod koniec XIV w. zaczęto określać świadczenia pieniężne w kopach groszy (grossi), które w niedługim czasie wyparły z obiegu grzywny.

45 ,[1: Quantitas homicidii nobilium] Quod quicumque nobilis interfectus fuerit, [occisor] quinquaginta sexagenas grossorum minus duabus sexagenis pro capite ipsius solvere teneatur. Cum vero miles quivis interfectus fuerit, qui non est nobilis, sed solum habet ius militare, pro eius capite 20 sexagene grossorum solvi debentur". [IMT, t. 1, nr 39, art. 1, s. 57].

46 W statutach książęcych lud prosty występuje pod nazwą kmieci (kmethones), którzy wydają się stanowić grupę jednorodną i równą w obliczu prawa.

47 „Item. Gdibi myedzi kmyeczmy manzoboystwo by syąn sstało albo przigodzylo, tegdi za kmyecza zabitego zenye albo i dzyeczyem taky manzoboycza cztirzy kopi a xandzu albo dzyedzyczowy druge cztirzi kopi zaplaczicz ma". [Prawa, op. cit., s. 4; por. J. Lelewel, Księgi, op. cit., s. 135].

48 „Item quando aliquis miles kmethonem vulneraverit, tunc kmetho super eundem militem debet querulari, dominus vero eiusdem kmethonis circa iudicium assistere debet. Et si idem kmetho super adversario iudicialiter adquesierit, tunc talis dominus, cuius kmetho fuerit vulneratus, tres marcas recipiet; kmetho vero pro suis vulneribus sex scotos accipiet, penis ducalibus exceptis". [IMT, t. 1, nr 22, s. 32]; U Bandkiego powyższy przepis podano jako 13 i zatytułowano Poena pro verbere kmethonum [IP, s. 419], zaś w wydaniu Helcla został umieszczony na pozycji 15 [H, s. 273].

49 „Item. Gdi nyektori wlodica kmyecza zbiye albo rany tegdi kmyecz ma nayn zalewacz a pan tego kmyecza przed sandem staacz ma a gdi ten isti kmyecz na swem przeczywnyku zisczee sandownye tedi pan yegosch kmyecz bil ranyon albo zbith swego kmyeczya trzi grziwni vesmye a kmyecz za swe rani schescz skoth vesmye ale vini xanzancze ossobnye viyawschi”. [Prawa, op. cit., s. 4; por. J. Lelewel, Księgi, op. cit., s. 135].
} 
Szeroko pojmowane gwałty (violentia) zarówno na osobie, jak i na mieniu stanowiły odrębną grupę przestępstw, których wspólnym mianownikiem było użycie przymusu fizycznego. Do gwałtów na osobie zaliczano w szczególności porwanie albo zgwałcenie kobiety. W przekładzie Macieja z Różana umieszczono ustęp Gwalt kmyotownye (podany jako 17) ${ }^{50}$, który został pomięty we wszystkich redakcjach łacińskich. Na mocy powołanego przepisu jakiekolwiek użycie przemocy wobec niewiasty albo wdowy, a także zgwałcenie dziewicy lub panny, było zagrożone karą czterech grzywien zadośćuczynienia dla pokrzywdzonej oraz tyle samo dla księcia, bądź uprawnionych do pobierania kar urzędników książęcych, tytułem kary publicznej. Mając w polu uwagi nagłówek niniejszego artykułu, trzeba odnotować, że odnosił się tylko i wyłącznie do pokrzywdzonych wywodzących się z ludu prostego, na co niezbicie wskazuje również rodzaj i wysokość przewidzianej w nim kary.

W wydaniu Jakuba Sawickiego pominięto także przepis opatrzony u Jana Bandtkiego nagłówkiem De his, qui alios invadunt (podany jako siódmy) ${ }^{51}$, zaś u Antoniego Helcla umieszczony jako ustęp ósmy ${ }^{52}$. Niniejszy artykuł został również uwzględniony w tłumaczeniu Różańskiego, który umiejscowił go jako ósmy i zatytułował $O$ them gdi kogo gaba gwalthem $^{53}$. Powyższy przepis regulował sytuację procesową, gdy sprawców użycia przemocy względem pokrzywdzonego było więcej niż jeden (samotrzecz na czye albo samowthor ${ }^{54}$ ). Jeśli poszkodowanemu znany był tylko jeden z przestępów, można było wnieść formalną skargę do sądu tylko w stosunku do niego, pomijając resztę współsprawców. Wówczas pozwany, aby dowieść swojej niewinności, musiał oczyścić się z zarzutu przysięgą świadków, przy czym nie określono w jakiej liczbie. W przypadku nieuczynienia zadość wskazanemu obowiązkowi, przestępca miał zostać skazany na tyle kar, ilu było współsprawców, zaś pokrzywdzony nie mógł już wnieść skargi na pozostałych.

50 „Item. Gdi ktho smyalosczyąn zląc nyewyesczye albo wdowye gwalt vczinilbi albo dzewcze dzyeviczstwo albo panyenstwo zgwalczil, cztirzi grziwni za thaky gwalt dacz bandze vynen viyawschi vyni xanzancze sandzi albo ktorich kole gyanshich czestnykow”. [Prawa, op. cit., s. 4; por. J. Lelewel, Ksieggi, op. cit., s. 135].

51 „Item si evenerit: quod super aliquem hominem inimieus, vel quispiam alius, eum complicibus suis mettertius, vel metdecimus, vel pluribus personie violente irruerit et invaserit, ipsum interficere volens, seu ei aliquid impedimentom inferre cupiens, si tunc ille, super quem invasio facta est, aliquem ex eis cognoverit, talem ad judicium citare debet pro hujusmodi violenta invasione, et ille, qui pro tali excessu inculpatur, debet suam Innocentami cum plenis testibus expurgare, ita, quo cum illis nunquam super eum invasit, neque superequitavit, manu violenta, et animo malo interficiendi eum, aut aliquo impedimentom sibi inferendo. Et si innocentiam suam hoc modo expurgaverit, liber erit a citatione et inculpatione, si vero non expurgnaverit innocentiam suam, talis in toto et in poenis condemnabitur, in quo actio fuerit contra ipsum mota judicialiter. Et eo facto idem actor postea, quos serum in eadem invasione fore crediderit, non debebit pro eodem facto impedire". [IP, s. 418].

52 „Item, si contigerit, quod super aliquem hominem inimicus vel quispiam mettertius vel secundus irruerit, ipsum vulnerare vel interficere volens, seu aliquod nocumentum et inferre, et si tunc [ille], super quem venerant, unum ex eis cognoscere valuerit, illum ad judicium citare debet, et ille, qui est pro tali excessu inculpates, debet suam innocentiam cum testibus expurgare et exbrigare, ita, quod cum eisdem, qui super eum venerant, in communitate non fuisset equitatus". [H, s. 271].

53 „Item. Acz bi syąn przigodzilo zebi nyektori nyeprzyiaczel albo kthokolibąncz samotrzecz na czye albo samowthor na nyekogo wrzvczil syan gy zabycz chczancz albo yemu nyektore gabanye vczinycz zandayancz pakli on na kogo przischly yenego s nich posnacz może takiego do sandu poswacz ma a tey ktorisch o thaky grzech obvynyon ma svoyąn nyevinnoscz se swyathky oczisczycz tako ze s nymy naan nyeyesdzyl a gdi nyevinnoscz oczisczy praw bandzye paklibi nyeoczisczyl tedy $w$ tako vyele vin potaupyon bandzye w yako vyelu zaloba naan bila a potem ten isti isczyecz drugich ktorich syąn domnyma ze s nym bily o than rzeecz nyema gabaacz". [Prawa, op. cit., s. 2-3; por. J. Lelewel, Księgi, op. cit., s. 134].

54 Tamże. 
Osobną grupę przestępstw dochodzonych na podstawie skargi prywatnej stanowiły przestępstwa przeciwko czci szlacheckiej, do których zaliczano w szczególności potwarze (oszczerstwa), zniesławienia oraz zniewagi. Podniesione czyny zabronione były karalne tylko i wyłącznie wówczas, gdy poszkodowanym była osoba wywodząca się ze stanu uprzywilejowanego. Wszystkie wskazane ujmy na honorze były traktowane jako zarzut nieszlachectwa, który w omawianym okresie na Mazowszu nazywano przyganą szlachectwa ${ }^{55}$. Czynność mającą na celu zmazanie plamy przygany nazywano oczyszczeniem. Statut książęcy z 27 kwietnia 1377 r. zamykał ustęp 17, Quantitas vituperii militis per militem ${ }^{56}$ (w przekładzie Macieja z Różana również na ostatniej pozycji, tj. 20, i zatytułowany Vyna prziganna gdi wlodica przigany wlodicze $e^{57}$ ), normujący powyższe kwestie.

Znieważony, który wniósł skargę do sądu, musiał dowieść swojego szlachectwa przysięgą świadków, a konkretnie po dwóch z każdego rodu, czyli łącznie sześciu. Przeprowadzenie powyższego dowodu było równoznaczne z dokonaniem oczyszczenia. Jednocześnie niniejszy przepis przewidywał za niesłuszne przyganienie szlachectwa karę, która wynosiła po pięć grzywien należnych zarówno pokrzywdzonemu, jak i księciu. Warunkiem orzeczenia wskazanej kary było oczyszczenie się pokrzywdzonego z przygany szlachectwa $\mathrm{w}$ toku przewodu sądowego.

Regulacje z zakresu prawa karnego, ujęte w statucie sochaczewskim z 27 kwietnia 1377 r., zajmują wyeksponowane miejsce na tle reszty unormowań prawnych. Prawu karnemu poświęcono łącznie, biorąc pod uwagę zarówno tekst łaciński, jak i przekład na język staropolski w tłumaczeniu Macieja z Różana, aż 12 ustępów, co stanowi ponad połowę wszystkich przepisów. Większość artykułów odnosiła się do materialnego prawa karnego, zaś tematyka procesowa została zarysowana jedynie ogólnie, albowiem dotyczyła niemalże tylko i wyłącznie zasad przeprowadzania dowodu z przysięgi świadków. Dużo miejsca poświęcono złodziejstwu oraz szeroko pojętym gwałtom, co zapewne znajdowało uzasadnienie w problemach dnia codziennego poddanych mazowieckich dynastów piastowskich. Jednocześnie należy zauważyć, że władcom Mazowsza zależało na wszystkich poddanych, ponieważ w statucie znajdują się unormowania dotyczące zarówno stanu uprzywilejowanego, jak i ludu prostego. Odtąd każdy mieszkaniec ziemi mazowieckiej mógł się powołać na konkretny przepis, uprawniający go do dochodzenia sprawiedliwości. Jednakże na wybitne uznanie zasługuje regulacja w zakresie wróżdy, ujęta w ustępie siódmym, ponieważ w prawie koronnym próżno szukać jakichkolwiek unormowań w tym zakresie.

Pierwszy statut mazowiecki wyróżnia się starannością redakcji oraz szerokim zakresem poruszonych zagadnień. Kolejne statuty książęce co do zasady obejmowały już tylko wyselekcjonowaną, wąską tematycznie, problematykę. Omawiany akt rozpoczął prężną działalność

55 W. Semkowicz, Nagana i oczyszczenie szlachectwa w Polsce XIV. i XV. wieku, Lwów 1899, s. 6.

56 „Item quando aliquis miles alicui militi vituperium intulerit, extunc ille, cui vituperium est illatum, suam miliciam approbando, debet statuere ex sua geneloya duos pociores et seniores, de duobus geneloys aliis per duos testes producere debet in testimonium, et cum approbaverit, extunc ille diffamans diffamato quinque marcas pro vituperio et V duci dare debebit". [IMT, t. 1, nr 22, s. 33]; U Bandkiego powyższy przepis umieszczono jako przedostatni, tj. 16, i opatrzono nagłówkiem Quantitas vituperii militis per militem [IP, s. 420], zaś w wydaniu Helcla został podany jako ostatni, czyli 18 [H, s. 274].

57 „Item. Gdi kto komu przigany tho yest wlodica wlodicze tegdi on komu prziganyono swoje wlodziczstwo ma dowyescz stawyancz $s$ wlostnego rodu dwu lepschu i starschu a se dwu rodu dwu lepschu tho yest s kazdego rodu dwu powyescz ma na swyadeczstwo a gdisch doswyatczi tegdi on ktori prziganil pyancz grziwen onemu komu prziganil a pyąncz grziwen xandzu dacz ma". [Prawa, op. cit., s. 4; por. J. Lelewel, Księgi, op. cit., s. 136]. 
ustawodawczą władców Mazowsza, którzy począwszy od 1377 r. ogłaszali liczne statuty ${ }^{58}$, a także edykty ${ }^{59}$, dekrety $^{60}$, mandaty $^{61}$ oraz ordynacje ${ }^{62}$. Powyższe uprawnia do wyciagnięcia wniosku, iż w dwóch ostatnich stuleciach swojej suwerenności Mazowsze zdystansowało Koronę w dążeniu do uporządkowania i zunifikowania rodzimego systemu prawnego.

\section{The regulations in the field of criminal law in the Sochaczew statute (27 April 1377) Summary}

This article is the first comprehensive overview of the criminal regulations of the first Statute of Mazovia, which was announced by Prince Siemowit III of Masovia on April 27, 1377 in Sochaczew. The authoress examines 11 criminal laws, which cover more than half of the act. The article presents the legal and penal regulations concerning: the conditions of taking revenge, villainy (robbery and persistent thievery), broadly defined rape on a person, the amount of were-gild for murdering a Włodyka (a representative of lower knighthood) and a well-to-do peasant, complicity, the defamation of people of high rank (ie. the rebuke of nobility), the requirements on which one can exonerate themselves in court, as well as the amount of compensatory damages for beating or wounding a well-to-do peasant. While discussing specific legal articles, the authoress explains the basic notions concerning mazovian criminal law both substantive and procedural, in particular: the penalty of proscription, a vendetta, the penalty of infamy, the rebuke of nobility, exoneration, were-gild and punitive damages. At the same time, the article presents the issue of the death penalty and confiscation of one's property, which were the most severe penalties for convicted criminals. The article concludes with the summary of the conducted research.

Keywords: mazovian law, criminal law, Sochaczew statute, manslaughter, villainy

Nota o Autorze: dr Patrycja Ewa Herod jest absolwentką Wydziału Prawa i Administracji Uniwersytetu Warszawskiego (2008) oraz ukończyła studia historyczne na Uniwersytecie Kardynała Stefana Wyszyńskiego w Warszawie (2011), gdzie obroniła z wyróżnieniem rozprawę doktorską pt. Rozwój prawa mazowieckiego na tle przeobrażeń polityczno-ustrojowych Mazowsza do XVI wieku pod kierunkiem prof. dr hab. Jolanty M. Marszalskiej (2014). Ponadto wykonuje zawód adwokata w Izbie Adwokackiej w Warszawie (od 2013). Głównym przedmiotem jej zainteresowań badawczych jest historia średniowiecza, ze szczególnym uwzględnieniem historii prawa oraz ziemi mazowieckiej. Jest autorką kilku artykułów, poświęconych przede wszystkim średniowiecznej historii Mazowsza, oraz opracowała ponad 40 haseł przedmiotowych, które ukazały się w Encyklopedii Katolickiej.

58 Do czasów obecnych dotrwało 46 statutów, z blisko 262 artykułami, ale trzeba podkreślić, że ich liczba zależy od danej redakcji, z której zliczało się poszczególne ustępy, więc można doliczyć się ich znacznie więcej.

59 Zob. np. IMT, t. 2, nr 220, 222.

60 Zob. np. IMT, t. 2, nr 251.

${ }_{61}$ Zob. np. IMT, t 2, nr 203-204, 210, 219, 227, 240-241, 245, 253, 257.

62 Zob. np. IMT, t. 2, nr 193. 